\title{
Quedar por significar. Efecto de extrañamiento y subversión de las imágenes
}

\section{To stay for meaning. Efect of estrangement and subversion of the images}

\author{
LUIS PUELLES \\ Universidad de Málaga (España)
}

Recibido: 3-XI-2015 Aceptado: 17-XI-2015

\section{RESUMEN}

Las páginas que siguen se ordenan a través de ciertos motivos filosóficos y artísticos posibilitantes y constitutivos de la experiencia moderna de extrañamiento: primero indagaremos en la confrontación nietzscheana entre arte y verdad, procurando extraer de ella algunas pistas hermenéuticas, y a continuación se buscarán las condiciones para observar cómo hacia la mitad del siglo XIX se asiste a una querella entre las imágenes y los signos, afanadas las primeras en desprenderse, desplegando recursos propios, de su subordinación tradicional -al menos desde el academicismo del siglo XVII-a las exigencias de la siginificación. De este modo podremos dotarnos de la perspectiva necesaria para comprender la estrecha ligazón de la soberanía artísticas de las imágenes con el destino inauguralmente moderno de inversión del platonismo.

PALABRAS CLAVES

EXTRAÑAMIENTO, IMAGINACIÓN, IMAGEN, PINTURA, FIGURALIDAD

\section{ABSTRACT}

The pages that follow are ordered according to certain philosophical and artistic motives that make possible and constitutive the modern experience of estrangement: first we will look into

(C) Contrastes. Revista Internacional de Filosofia, vol. XXI-Nº3 (2016), pp. 23-37. ISSN: 1136-4076

Departamento de Filosofía, Universidad de Málaga, Facultad de Filosofía y Letras Campus de Teatinos, E-29071 Málaga (España) 
niestzschean confrontation between art and truth, trying to extract from it some hermeneutic tracks, and later, we will look for the conditions to observe how towards the middle part of the $19^{\text {th }}$ century we witness a quarrel between the images and the signs, where the first ones strive detach, and displaying their own resources, form their traditional subordination -at least from the academicism of the $17^{\text {th }}$ century- to the requirements of the meaning. Thus we will be able to provide ourselves with the necessary perspective to narrow attachment of the artistic sovereignty of the images with the modern opening destination of reversing of the Platonism. KEYWORDS

ESTRANGEMENT, IMAGINATION, IMAGE, PAINTING, FIGURALITY

\section{CREAR CONTRA LA NADA: EL GOZNE DEL SIGLO XIX}

COMENCEMOS LEYENDO UNA FRASE DE NIETZSCHE que, a oídos de Heidegger, según él mismo confiesa, «suena monstruosa». La escribe en 1888, mientras reflexiona sobre lo que se propuso en su primera obra, El nacimiento de la tragedia. Es esta: «La relación del arte con la verdad fue lo primero que me preocupó: y aún hoy estoy con un pavor sagrado ante esa discrepancia» (XIV, 368; citado en Heidegger 2005, 78). Estas palabras sitúan en el origen del pensamiento nietzscheano cierta discrepancia, capaz de resultar pavorosa -aún más: de un modo sagrado-, entre dos esferas de la cultura humana marcadas por haber mantenido relaciones tensas entre sí, en las que las sospechas recíprocas de diversa índole no han cesado hasta la actualidad. Por una parte la verdad, sostenida en una tradición de raigambre platónica y cristiana que la entiende en términos metafísicos y esencialistas, y, por otra, el arte, creación prometeica definida por su propia historicidad. Pero, más allá de que nos decidamos a adentrarnos en la búsqueda de otras implicaciones supuestas en esta discrepancia, las cuales nos conducirían a determinados aspectos internos del trayecto seguido por Nietzsche, resulta sorprendente -como una especie de sacrilegio filosófico-que se posibilite en esta frase la confrontación, a primera vista inadecuada, o impertinente, entre un ámbito de estricta determinación teorética, capaz de permanecer absoluto, y este otro, el del arte, de clara pregnancia poietica.

¿Por qué tiene la verdad que («rebajarse» a) entrar en tratos - de discrepancia o no- con una actividad tan mutable, tan relativa a lo humano, como es esa a la que llamamos creación artística? Y sobre todo: ¿A partir de cuándo se asiste a un abocamiento de la verdad hacia lo artístico, a una especie de igualación -acaso monstruosa: no natural-de las posibilidades de dotación de sentido procedentes de ambos dominios antropológicos? Se trataría entonces de vislumbrar una crisis de época, de detectar una cierta génesis o umbral de la cultura moderna que nos descubra la arqueología de este tener que entrar en relación, ella misma poco idónea a la tradición filosófica de raigambre platónica tenazmente sostenida en la ignorancia -también en el temor- de lo 
artístico. ¿Cabría entender que tal relación se evidencia como un pulso, o un duelo, justamente cuando cabe advertir incómodos desacuerdos, disensiones, desobediencias llevadas a cabo por la acción del arte confrontándose con la verdad? (Incluso podríamos aventurar que el arte es en la modernidad -o sea, cuando se centra y concentra en llegar a ser «sí mismo»- en tanto que se da por tarea principal la configuración de estas insubordinaciones contra-teoréticas). ¿Por qué estas discrepancias llegan a ser «pavorosas»? O sea, ¿por qué la cercanía entre la verdad y el arte pudiera asustarnos, sobresaltarnos, descubrirnos algún motivo al que temer?

Avancemos con cautela en el intento de desbrozar alguna respuesta a estas cuestiones. Y empecemos trasladándonos a un enclave histórico suficientemente reconocible. Nietzsche está refiriéndose, al escribir estas palabras, a sus primeros años de producción intelectual, alrededor de 1870, pero podríamos tomar la mencionada discrepancia como un umbral de instauración advenido con anterioridad a estos años del joven profesor en Basilea: la irrupción del arte, proteico y prometeico, antropomórfico y, sobre todo, «antropognóstico», instado a emprender misiones que no se conforman ya con la glorificación de dioses y poderosos, ni con la factura de la forma bella, se produce en los primeros años del siglo XIX, en esa época que solemos identificar bajo las marcas del Romanticismo. Creo que es ahí donde conviene situar las primeras tensiones irrevocables entre una verdad que, perdiendo su dimensión metafísica, ya no nos salva de nuestro creciente sentimiento de orfandad (ateísmo y nihilismo tienen su cogénesis romántica en autores como Jean Paul) y una voluntad de arte impulsada por la necesidad -ella misma pavorosa y sagrada- de que sean nuestras propias empresas humanas las que nos auxilien en la difícil misión de cargar con la nada. $\mathrm{O}$, si se quiere, de cargar con algún sentido que nos libre de abismarnos en la nada. Como nunca antes, «el arte es el contramovimiento por excelencia frente al nihilismo» (Heidegger 2005, 76). La acción creadora, que no sólo no debe confundirse con la mera actitud estética en lo que ésta tiene de reactiva y contemplativa, sino que se le opone de tal manera que el arte se confronta violentamente con la recepción estética, sale a la escena de la cultura para contrarrestar la expansión del nihilismo (teoricista) ${ }^{1}$.

Insistiendo algo más en esta discrepancia -advenida en el gozne hacia el siglo XIX - entre verdad y arte, podríamos darle otra complejidad más precisa, proponiendo el enfrentamiento entre conocimiento y creación. Sin necesidad

$1 \mathrm{Al}$ ser esto así, es por lo que resulta idóneo compartir la última proposición formulada por Heidegger en su lectura de Nietzsche, a quien expresamente cita (n. 853, IV): «El arte tiene más valor que "la verdad"». El arte nos sirve más que la vieja verdad de fundación platónica. «La voluntad de apariencia, de ilusión, de engaño, de devenir y cambio es más profunda, más "metafísica" que la voluntad de verdad, de realidad, de ser» (Nietzsche, XIV, 369; citado en Heidegger 2005, 77). 
siquiera de postular el concepto fuerte de verdad -o de mundo verdadero- en sentido platónico ${ }^{2}$, bastaría con apuntar a un aspecto concreto de este juego de viejas oposiciones. Es en estas décadas cuando se produce una fuerte convulsión, consistente en que el estatuto clásico del conocimiento deberá compartir su hegemonía con una noción de firme aversión teórica: la de poiesis, la cual, por cierto, venía soportando, desde la instauración de las Academias y las poéticas clasicistas del siglo XVII, una reglamentación reductora que ahora se descubrirá del todo estéril. A la superioridad de la theoria, del conocimiento por abstracción e identificación, le sucede -arrabatándole parte de sus privilegios- un saber demoníaco, el de la creación por diferenciación, un modo de saber originar de mayor vocación concretante e individualizante que ratificante de la mismidad. Al conocimiento, que lo es de lo mismo, la cultura romántica opone la creación de lo otro.

De acuerdo con esto, el primado tradicional del concepto se verá desestabilizado por los nuevas cotas de soberanía que obtendrá la imagen para sí. Más abajo recuperaremos este asunto del estatuto decimonónico de la imagen en su querella con los signos, pero no queramos apresurarnos y demos todavía alguna atención a un factor que acompaña al anterior: a la creación-de-lo-otro es preciso afiliar una cuestión fundamental, y es que al viejo predominio de la belleza sucede, en este viraje sucedido en los inicios del siglo XIX, la proliferación de nuevos registros de sensibilidad y sentimentalidad, de indagación en una subjetividad que se ha vuelto de mayor complejidad que aquella que se reconocía en la antropología de impronta racionalista. El sujeto de distancia cognoscitiva y contemplación estética, un sujeto de entendimiento dominante del mundo en sus representaciones objetualizantes, entra en colisión con dominios de experiencia en los que, más que un sujeto de conocimiento, comienza a determinarse un sujeto de vivencia, presto a la complejidad de las emociones que impregnan la vida propia, las artes y los vericuetos de la ficción. Frente a la serenidad ensimismada de la belleza -en cuya constitución clásica arraigan la verdad, la plenitud ontológica y el bien moral- se despliegan, ahora ya en el escenario naciente de la ciudad moderna, «categorías estéticas» dirigidas a la provocación del efecto excitante, intenso, de difícil asimilación a lo ya conocido $\mathrm{y}$, por lo tanto, regidas por la obtención de la novedad y el shock ${ }^{3}$. El declive

2 «Voluntad de verdad quiere decir para Nietzsche, aquí y siempre: la voluntad del "mundo verdadero" en el sentido de Platón y del cristianismo, la voluntad de lo suprasensible, de lo que es en sí. La voluntad de lo "verdadero" en ese sentido es en verdad un decir no a nuestro mundo de aquí, que es precisamente donde tiene su casa el arte» (Heidegger 2005, 79).

3 «La amenaza de esas energías es la del shock» (Benjamin 1993, 130). Efectivamente, la caracterización de la experiencia chocante en términos de incapacidad de asimilación e impresión de extrañeza-implicándose así la turbación o la desorientación ante lo irreconocible- tiene escalas en Simmel y Valéry. Del primero podríamos recordar su escrito sobre «Las grandes ciudades y 
de la vieja belleza asiste a la ampliación de modos de la sensibilidad cultivados por las artes (estas, por cierto, cada vez más «imaginales» y también más industriales y espectaculares), tales como lo terrorífico y nuevos perfiles de lo grotesco (bastaría recordar el Prefacio a Cromwell, de Victor Hugo, de 1827), además de formulaciones hasta ahora desconocidas de lo trágico, lo cómico y lo demoníaco, la elaboración de la categoría de lo feo por Rosenkranz y de lo interesante por Kierkegaard, y el cénit de lo sublime...

En todas estas regiones del efecto estético destaca un factor decisivo: el viejo sujeto cartesiano, capaz de distanciarse del mundo para afirmar su dominio como «sujeto de representación» (o representaciones); dedicado afanosamente a la objetualización de lo inmediato, lo familiar, lo habitual, se encuentra de repente arrebatado de la distancia protectora, constitutiva del propio sujeto, para quedar relegado a ser objeto de la acción desestabilizante que la obra de arte dirige contra él (esto es, contra su facultad de entendimiento, contra su posición de privilegio cognoscitivo, contra su necesidad de fijar representaciones para evitar con ellas las turbulencias de la presencia opaca al sentido). La colisión entre conocimiento y creación ha acabado por cercar al sujeto estético bajo el triunfo de la obra como voluntad de acción poderosa.

El viejo sujeto protegido en su conciencia inalcanzable se halla ahora rendido a una experiencia que lo expulsa de la relación cognoscitiva de identificación. Ha perdido la capacidad de entender lo que siente (lo que se le hace sentir), y su vivencia - «alienada»- es de sobrecogimiento. Y esta acción poderosa, en términos de fuerza y eficacia, y no ya en los de signo entendible o forma bella, es producida por la imagen artística, en un siglo en el que es ella misma la que se vuelve «sujeto» enigmático e insurrecto, capaz de -como dice Benjamin del aura- levantarnos la mirada, de sublevarse, de hacerse «conciencia de sí»» (o, dicho de otro modo, soberanía y autoconocimiento): de mostrársenos irreductible, impenetrable por la reconocibilidad. Es efectivamente en este contexto de configuración de una subjetividad debida a la suscitación de experiencias más o menos «sobrecogedoras» cuando acontecen los primeros compases del efecto de extrañamiento.

Las obras inequívocamente modernas (Goya, Manet, Seurat) se erigen sobre el esfuerzo de no dejarse tomar por la identificación que las agota al reconocerlas. Y esto nos conduce a un aspecto latente a lo que decimos. Pro-

la vida del espíritu» (1903); de Paul Valéry, «Leonardo y los filósofos» (1929): «La Belleza es una especie de muerte. La novedad, la intensidad, la extrañeza, todos los valores de choque, la han suplantado. La excitación en estado bruto es la dueña soberana de las almas recientes; y las obras tienen actualmente por función arrancarnos del estado contemplativo [...]» (Valéry 1987, 111-2). Si bien ambos autores se están refiriendo a su propio tiempo, sostengo aquí que ya en las décadas intermedias del siglo XIX se originan los primeros indicios poieticos de suscitación del efecto extrañante. 
gresivamente liberadas de tener que servir a causas sacralizantes, glorificantes, simbólicas o de (alta o baja) significación ilusionística, las artes de la imagen se verán sometidas a la contraprestación de una nueva tiranía: la exigencia inexcusable de ser miradas. La leyenda a la que la teoría del arte suele referirse con la fórmula de «la autonomía de la obra de arte», señalándose con ella la emancipación-como marca de modernidad-del arte respecto de los poderes simbólicos y terrenales que tomaban a la obra en virtud de sus servicios y no por su naturaleza predominantemente «estética», no consigue realizarse, por la razón de que la imagen que se quiere soberana, a la vez que enfatiza su estatuto de imagen (ni símbolo ni signo) va siendo presa de la necesidad de ser acogida y nutrida por el ojo del receptor. Es la mirada del espectador la que les confiere - como al dandy-existencia y perdurabilidad. A cambio de perder densidad simbólica, las obras instauradas como imágenes soberanas deberán desplegar una sofisticación retórica creciente -y hasta ansiosa- en relación con la potencia de «seducción visual». Libre de rendir pleitesía a reyes o a dioses, desprendida ya del cumpliminento de obediencia al modelo al que copia, la imagen artística se verá condenada a retener ante ella al receptor voluble, volátil, escurridizo e ignorante. La obra moderna deberá hacer suya la estrategia -en la forma de un saber propio- según la cual obstruir la identificación alcanza a ser un recurso efectivo para que el receptor prolongue su tiempo de mirada. Veamos con algún detenimiento cuál es la épica de la imagen haciéndose mirar -y no participar o entender- a través del siglo XIX.

\section{OPONER LA PRESENCIA: QUERELLA DE LOS SIGNOS Y LAS IMÁGENES}

Para acceder a la complejidad de las controversias mantenidas entre la tradición de la obra de arte como signo, y, por lo tanto, como instancia susceptible de inteligibilidad, y la instauración de la imagen soberana es preciso recalar en un motivo de relevancia insoslayable en lo relativo a las especificidades del siglo XIX: la imaginación empieza a ser identificada por su función creadora, y no sin más reproductora o auxiliar memorística de la percepción.

Es un lugar común referirse a las transformaciones conocidas por la facultad de imaginar aludiendo a Blake, Coleridge, Wordsworth o Shelley. Por mi parte, prescindiré de esta importante tradición para concentrarme en dos autores con los que tensar un arco: Kant y Baudelaire. El primero ofrece algunas observaciones fundamenrales en la Crítica del juicio, donde enuncia que, «si en el juicio del gusto tiene que tomarse en consideración a la imaginación en su libertad, entonces ésta no es reproductiva, como sucede cuando está sometida a las leyes de la asociación, sino que tiene que tomarse como productiva y autosuficiente (como autora de formas libres de posibles intuiciones)» (Kant 2003, 194). Y más abajo, en el epígrafe dedicado a las capacidades del genio, se lee: «A partir de la materia que la naturaleza real le ofrece, la imaginación (en 
tanto que capacidad cognoscitiva productiva) es muy poderosa en la creación, por decirlo así, de otra naturaleza» (Kant 2003, 281). La imaginación podrá, entonces, ser creadora de lo nuevo: es -tal y como define el propio Kant al genio- un origen, un umbral de existencia nueva, cuya naturaleza es la de ser imagen insólita o imprevista. Es una obviedad, pero quisiera enfatizarlo: la imaginación produce imágenes. Y, según nos dice Kant, estas imágenes nacen de la libertad de una actividad dotada de suficiencia creadora para componer lo hasta entonces inexistente $\mathrm{y}$, sobre todo, desconocido a la visión.

Hagamos abstracción de los setenta años - decisivos para lo que tratamos de elaborar en estas páginas-que distan desde la publicación de la Crítica del juicio (1790) y el Salon de 1859 redactado por Baudelaire, más de medio siglo en el que la «facultad de Prometeo», como la define el poeta francés, no ha hecho más que expandirse y hacerse ominipresente, para encontrarnos con unos comentarios precisos y decisivos sobre la que recibirá los honores de ser «reina de las facultades». Baudelaire enfatiza esta expansividad de la imaginación filtrando con ella las otras facultades: «Ella toca a las demás; las excita, las envía al combate. A veces parece que vaya a confundirse con ellas, y sin embargo permanece siempre siendo ella misma» (Baudelaire 1968, 397). Pero además le asigna una función realmente crucial para lo que aquí me propongo: le atribuye la capacidad de descomponer lo que recibe y de crear, mediante la disgregación de lo que se nos daba unido, un mundo nuevo: «Ella descompone la creación entera, $\mathrm{y}$, con materiales amasados y dispuestos siguiendo reglas cuyo origen sólo están en lo más profundo del alma, crea un mundo nuevo [...]» (Baudelaire 1968, 397). Esta potencia de desobediencia respecto a las representaciones regladas por criterios metafísicos o estéticos de orden, armonía, unidad, cuales son las sostenidas a lo largo del clasicismo y el neoclasicismo, requiere del artista que se dé a recomponer, de forma original y fuertemente subjetiva, un mundo posible; que se entregue a la tarea prometeica de alterar las significaciones sostenidas en la estabilidad de lo dado como idéntico a sí mismo. En este punto, aún abusando de las citas, bien merece leerse lo que el propio Baudelaire nos presenta como «la fórmula principal» de la verdadera estética: «Todo el universo visible no es más que un almacén de imágenes y de signos a los que la imaginación dará un lugar y un valor relativo; es una especie de pasto que la imaginación debe digerir y transformar. Todas las facultades del alma humana quedan subordinadas a la imaginación, que las pone a todas a la vez bajo su dominio» (Baudelaite 1968, 399). Corresponde a la libertad de la función imaginante disponer del orden recibido, jugando a los equívocos y las arbitrariedades, a las suspensiones de la verosimilitud y las obstrucciones de la reconocibilidad.

En rigor, podríamos suponer que esta superioridad de la imaginación habrá de conllevar el aniquilamiento defintivo de todo realismo obediente. La 
imaginación obtiene con todos los honores la potencia de insurgencia respecto a la ecuación que dota de mayor crédito ontológico a lo real percibido que a lo posible sugerido. Las imágenes que ella crea gozarán al fin de la mayor libertad ${ }^{4}$. A cambio, deberán conducirse hacia la seducción del espectador.

Pudiendo descomponer lo recibido (lo mismo) y dotada de las condiciones de crear lo otro, la imaginación se afirma como el medio prometeico con el que la obra de arte se resuelve ahora, en términos ontológicos, bajo la exigencia de producir imágenes (y no sin más «copiarlas» o reproducirlas; o sea: de crearlas y no sólo de recrearlas para la complacencia estética). De producirlas para ser miradas. Las artes visuales deberán despeglar diversos medios de atracción y atrapamiento, hasta el punto de que la historia del arte podría comprenderse, a partir de las décadas intermedias del siglo XIX, como un itinerario de múltiples recursos de experimentación conducentes a tal finalidad.

Estos recursos podrían clasificarse a través de dos grandes vectores, dos líneas de fuerza que han definido sendas épicas de la imagen artística soberana entre Manet y el siglo XX: por una parte se encuentra la gran tradición estetizante, plasticista y formalista que, de un modo u otro, nos lleva a las diversas Abstracciones, y, por otra, se define ésta a la que nos estamos refiriendo, dedicada a extrañarnos -más que a «ensimismarse» en su propia vanidad- de la identificación mediante el equívoco del signo y la figuralidad confusa e ilegible ${ }^{5}$. En ambas tradiciones la obra de arte se libra a la batalla de convertirse en imagen soberana (la modernidad, desde - cierto- Ingres, Goya, la fotografía, Manet, es el campo de esta batalla). Es afirmándose en la tensión prolongada de este combate como la imagen se instituye como presencia: como aparición y acontecimiento.

4 Clément Rosset define la imaginación en clave moderna dotándola del factor de sugerencia, diferenciándola de la imaginación servil de la percepción y auxiliar de la memoria, a la que otorga la capacidad de evocación: «Tal es esencialmente la concepción de la imaginación que se puede llamar clásica: la imaginación es una sensación no únicamente disminuida (como lo muestran todos los análisis de la imaginación que oponen la palidez de la copia a los vivos colores del original), sino sobre todo una sensación constreñida [...]. Si al contrario se considera la imaginación como un poder de sugestión de imágenes libres y emancipadas respecto a lo real, extrañas al lote de imágenes ofrecidas a la percepción ordinaria, la función de la imaginación no consistiría ya en evocar las percepciones, sino más bien en distraerse en la producción de "representaciones" tan preciosas como que ellas no representan nada de lo ya conocido, es decir, no representan nada» (Rosset 2006, 94-5).

5 Acerca de este concepto de «figuralidad», debo explicitar que lo empleo y sobreentiendo aquí siguiendo las propuestas de Jean-François Lyotard en Discours, figure (1971): lo figural se definiría ganándose contra lo textual. 
El vector estetizante nos permitiría restaurar una vez más el viejo relato de los avatares de la plasticidad hasta hacerse con la conquista «formalista» de la autorreferencialidad. Este camino, que, según está convenido y reiterado, se prolongaría entre la poética manetiana de la insignificancia platicista y las telas de Pollock, con escalas obligadas en Cézanne, los postimpresionistas y los fauves, el cubismo y los pioneros de la abstracción en las vanguardias históricas menos ideologizadas, ha elaborado con insistencia lo que podríamos llamar la expulsión del signo, o, si se prefiere, su negación. En tales casos se trataría de romper con los servicios al/del signo, sacándolo del espacio de la composición. Tal insurrección contra la significación propiciaría que la imagen artística se creyera soberana -ya en sus últimos estadios- por creerse «absoluta» - esto es, no relativa a nada que no sea ella misma.

Es sin embargo el segundo vector de la confrontación entre los signos y las imágenes el que nos interesa aquí. Frente a la negación o supresión del signo, se trataría más bien de minar de equívocos su pretendida transparencia. De conservar el signo enrareciéndolo, alterándolo, sometiéndolo a la ironía practicada sobre él por la imagen. Las posibilidades «subversivas», en términos cognoscitivos, contenidas en este procedimiento fueron ya advertidas y temidas por el propio Platón, quien se apresuró a la expulsión de las imágenes engañosas. Una expulsión, por cierto, que nunca es definitiva, que siempre debe ser revisada; y esto es así porque, como es claro, el signo está en la imagen, y, en gran medida, está cautivo de ella (la pintura de Ingres se mantiene en esta posibilidad: el signo está acechado por la imagen -que es-). Cabría afirmarse que el signo posee una naturaleza esquiva, tornadiza, ambigua, nunca del todo capturada por el entendimiento para componer la representación. Como acabo de decir, esto lo supo Platón, y es esto mismo lo que de manera fundacional se nos cuenta en el himno homérico dedicado a Hermes, el mensajero de los dioses, capaz de alterar las huellas para no ser alcanzado después de haber robado las vacas a su hermano Apolo. Hermes, del que se espera que nos dé los signos claros, es justamente quien sabe cómo velarlos para volverlos imágenes equívocas o confusas. Esta segunda tradición es, digámoslo de este modo, la del signo alterado y, por lo tanto, perturbador, la de la imagen centrada en extrañar la identificación-reconocibilidad de lo que nos venía pareciendo «suficientemente» conocido.

Hay por tanto una modernidad paralela a la de los grandes hallazgos formales y opticistas, y en ocasiones convergente con ella, porque, efectivamente, según lo entiendo, las dos se originan en Manet -advirtiendo, por cierto, una ambivalencia en este pintor que es sistemánticamente reducido a «indiferencia» sobre el sujet y afirmación del plasticismo-, y las dos convergen en autores como Cézanne o Seurat; también en episodios fundamentales, tales como la instauración del collage y las conquistas del cubismo, los cuales despliegan 
sus artes abocándonos al vértigo de la identificación, a la desestabilización de la representación (o a sus «disonancias» ${ }^{6}$ ). Donde creíamos encontrar, en el signo, transparencia y transitividad, además, desde luego, de un funcionamiento impecable -o sea, imperceptible- y la voluntad afanosa de negar su propia arbitrariedad, de imponer alguna univocidad sosegante a fuerza de repeticiones, nos topamos abruptamente con desarreglos, con desajustes, con collages impenetrables, ante presencias en inmanencia donde quisimos que hubiera puzles ilusionándonos con algún sentido bien fijado: estable y estático. Habitable por el entendimiento y sus órdenes. Los primeros desajustes o disfunciones aparecen justamente en Manet, en cuya pintura se hacen evidentes los signos que habrían de permanecer sin ser visibles y sí del todo legibles. Manet es la ironía por la que el signo se vuelve evidente; por la que al signo se le ve la imagen. Se abre con él -con cierta antesala en el Ingres más inquietante y en el último Goyaun trayecto que alcanza al simbolismo, la pintura metafísica y el surrealismo. En todo caso, estas páginas no tienen intención de trazar el trayecto aludido, limitándose a situar en la primera mitad del siglo XIX la arqueología de la imagen soberana y el efecto de extrañamiento que le es propia en algunas de sus dimensiones menos plasticistas y sí más equívocas.

Como puede comprenderse, esta segunda tradición de la querella de las imágenes y los signos, la del extrañamiento de la identidad, no renuncia al uso de las figuralidad. Hay imágenes que parecen significar (pensemos en De Chirico, o en Magritte), que parecen poder ser identificadas, pero enseguida se nos dificulta que podamos volverlas inteligibles (y acaso así invisibles). Demos a este asunto toda su relevancia permitiéndonos un rodeo.

\section{INVERTIR EL PLATONISMO. LA IMAGEN EN PRESENCIA.}

Las imágenes antiplatónicas traídas por el arte de la modernidad existen a la ofensiva, en tanto que se resisten a ser sometidas a la verdad -de este modo volvemos a encontrarnos con las palabras de Nietzsche que nos abrieron el camino de estas páginas. $Y$ existen mientras saben -o sepan- mantenerse en esta resistencia; a ser intelegidas, o, sin más, a ser leídas. Por esto son phantasmas, para «aparecerse» sin poder ser atrapadas por la significación clausurante y estabilizante. En colisión con la imagen figurativa, la imagen simulativa o fantasmal -utilizando aquí los términos diferenciadores del Sofista platónicofigura en falso, no obedece al modelo pero sí se le parece, hasta seducirnos en la ilusión de suplantarlo. «Si sólo aparenta parecerse, sin parecerse realmente, ¿no será una apariencia [phántasma]?» (Platón 1998, 381).

6 Quizá nos sirva a este respecto esta lacónica afirmación de Adorno: «La disonancia, el signo de toda la modernidad» (Adorno 2004, 27). La creación artística atareada en hacernos perder las evidencias cognoscitivas -y sólo accidentalmente ópticas- se sirve de disonancias. 
Es común referirse al artículo de Deleuze «Renverser le platonisme» (1967), integrado con modificaciones en Logique du sens (1969), para adentrarse en las implicaciones contenidas en la inversión del platonismo practicada por Nietzsche. En él, refiriéndose al Sofista, Deleuze declara: «[...] Platón divide en dos el dominio de las imágenes-ídolos: por una parte las copias-iconos, por otra los simulacros-fantasmas [...] Se trata de asegurar el triunfo de las copias sobre los simulacros, de reprimir los simulacros, de mantenerlos encadenados al fondo, de impedirles que asciendan a la superficie y se "insinúen" por todas partes». (Deleuze 1969, 296). La elección en estas líneas del verbo «refouler» (que prefiero traducir como «reprimir», o «inhibir», significando también «rechazar» o «expulsar») es expresiva de cómo trabaja la insurgencia de la imagen moderna: liberándose, dándose a la conquista de su propia liberación. El trayecto seguido por la imagen extrañante, desde Goya y Manet hasta Bacon, compone el relato de sus propias «hazañas» para sustraerse de cuanto, en virtud de la inteligibilidad, las inhibe, las relega a la condición de mera obediencia a lo real.

Las imágenes fantasmales no se prestan a ser copia de un modelo; no son iconos, sino imágenes que se nos ponen delante y tratan de seducirnos; nos encantan, nos fascinan, nos retienen en ellas dificultando o impidiendo el -incierto y también ilusorio- acceso a la verdad. Su identidad no es otra que la de mostrarse. Son apareciéndose, y no sin más apariencias. En ellas se libra el combate entre la apariencia de la copia y el acontecimiento del simulacro. Y es este combate el que determina el destino de inversión del platonismo que hace suyo el arte a partir del Romanticismo: la violencia por mostrar los simulacros, por «afirmar sus derechos entre los iconos o las copias. El problema ya no concierne a la distinción Esencia-Apariencia, o Modelo-copia. Esta distinción opera enteramente en el mundo de la representación; se trata de introducir la subversión en este mundo, "crepúsculo de los ídolos". El simulacro no es una copia degradada; oculta una potencia positiva que niega el original y la copia, el modelo y la reproducción» (Deleuze 1969, 302). Efectivamente, no se trata ya de dotar de algún predominio a lo sensible, propiciando su ennoblecimiento frente a lo inteligible; no estamos en las metafisicas dedicadas a discernir el «arriba» y el «abajo», ni mucho menos en la ontología, con sus implicaciones cognoscitivas, de la participación de lo material en lo ideal. Se trata de crear una imagen ajena a tener que cumplir las exigencias que le impone alguna otra instancia-Verdad, Realidad, Idea-. El simulacro existe sin pedir permiso. Su determinación mayor es la de imponerse como presencia mostrándose.

Me parece oportuno, llegados aquí, ofrecer de modo sintético tres características por las que la imagen artística soberana se gana a sí misma como presencia irreconocible, de tal manera que la acción artística dirige sus empeños a hacerse-presencia, entorpeciendo la obtención de la significación y actuan- 
do en la afirmación de lo que Derrida llama différance (buscando diferenciar lo que se muestra de lo que se sabe -contra el Menón-y buscando diferir y posponer la posibilidad de llegar a saberlo). La imagen artística, demoníaca, vive a condición de no tener que servir a la luz (ni de cumplir la misión de la aletheia); a condición de desplegar sus velamientos. Vive afirmando lo visible contra lo evidente. Veamos estas tres propiedades de la imagen extrañante.

La primera propiedad es la opacidad o el enigma. La imagen debe preservar un resto de mostración irreductible a representación entendible. Adorno se ha detenido en este carácter de la obra de arte, sobre el que aporta dos interesantes apreciaciones: es enigmático lo que a la vez que se muestra se oculta: «Todas las obras de arte, y el arte en conjunto, son enigmas; esto ha irritado desde antiguo a la teoría del arte. Que las obras de arte digan algo y al mismo tiempo lo oculten es el carácter enigmático desde el punto de vista del lenguaje» (Adorno 2004, 164-5). Además, es intrínseco al enigma permanecer como reducto inexplicable («El carácter enigmático se conoce como constitutivo donde falta: ninguna obra de arte se revela a la consideración y al pensamiento sin restos» (Adorno, 2004, p. 166). Son estos restos de opacidad los que nos retienen ante la imagen, capturados por su propia ininteligibilidad. La imagen, sabiendo aparecerse inmanente y sensible, es lo que queda sin poder ser enteramente poseída por la idea. (Podríamos recordar aquí aquel sustrato de caos que, por su naturaleza material, queda sin ordenar -impenetrable- por el Demiurgo del Timeo platónico).

La segunda característica que podemos advertir en la imagen soberana y de figuralidad extrañante es su ambigüedad. Se hace difícil no referirse en este punto al escrito de Umberto Eco Obra abierta: «[...] la obra de arte es un mensaje fundamentalmente ambiguo, una pluralidad de significados que conviven en un solo significante. [...] esta ambigüedad -en las poética contemporáneas- se convierte en una de las finalidades explícitas de la obra, un valor que conviene conseguir con preferencia sobre los demás» (Eco 1985, 34).

Eco sitúa en el poema de Verlaine Art Poétique la primera expresión dedicida de ambigüedad. No está lejos la poética de la sugerencia cultivada por Mallarmé. Se trata de mantener abierta la posibilidad, en tanto que posibilidad, de la comprensión. En buena ley hermenéutica, comprender es justamente no entender del todo. Sin embargo, querría enfatizar que, según lo entiendo, es condición de la imagen de potencia extrañante evitar la indefinición o vaguedad en su factura formal y, digamos, meramente óptica. No es que resulten poco claras desde un punto de vista perceptualista, sino poco o dudosamente reconocibles. En este sentido, me atrevería a apuntar que el extrañamiento más efectivo se encuentra en ciertas muestras del naturalismo (pienso en El Horla de Maupassant), o incluso en la precisión de las natures mortes del pintor belga Léon Spilliaert, y, claro, en De Chirico, o incluso en Morandi, y en Magritte, 
que en las imágenes de ejecución borrosa - por ejemplo, en cierto Odilon Redon- en las que simplemente se distingue mal en términos plásticos el perfil preciso de la imagen.

El tercer rasgo de la imagen extrañante es el de fascinación. Es así como la imagen se cumple como presencia que nos apega a ella a la vez que nos excluye. Sobre esta condición, nos da Barthes una espléndida definición de la imagen (o mejor: de la supervivencia de la imagen como presencia) en sus Fragmentos de un discurso amoroso: «He aquí, pues, la definición de la imagen, de toda imagen: la imagen es aquello de lo que estoy excluido» (Barthes 1993, 154). Y debemos a Blanchot algunas reflexiones fundamentales sobre la fascinación: es «como si la mirada estuviese tomada, tocada, puesta en contacto con la apariencia [...] cuando la mirada es arrastrada, absorbida en un movimiento inmóvil y en un fondo sin profundidad» (Blanchot 1955, 25). En la fascinación, cautivos de la imagen, quedamos tocados, impedidos para la distancia protectora que nos permitiera ver y entender. Ante la imagen fascinante -algo así como una imagen pura-se nos vuelve imposible penetrar algún sentido. Quedamos, como digo, tocados, tomados por objetos de la acción que nos arroja a la intemperie, que nos retiene en ella. «Lo que nos fascina nos quita nuestro poder de dar sentido» (Blanchot, 1955, 25-6). Efectivamente, es constitutivo de la experiencia de extrañamiento la impenetrabilidad de la imagen, su opacidad: su resistencia al sentido que trata de representársela. En el estado de fascinación nos quedamos fijados en el afuera, retenidos a la intemperie, sin el asidero con el que el entendimiento gana la representación para poder así apartar a la imagen $\mathrm{y}$, dotándola de significaciòn, obtener dominio sobre ella. Cuando esto se cumple, la imagen queda relegada a objeto de mera complacencia estética o, sin más, a signo servil.

Siendo impenetrable, la imagen se aleja de ser objeto; aún más, de limitarse a cumplir funciones sustitutorias de los objetos. La presencialidad de la imagen impensable pasa por la condición de suplantar a los objetos. Por eso -volviendo al Sofista- son simulativas y no figurativas. Sigamos leyendo a Blanchot: «La imagen de un objeto no sólo no es el sentido de este objeto y no ayuda a su comprensión, sino que tiende a sustraerlo, manteniéndolo en la inmovilidad de una semejanza que no tiene a lo que parecerse» (Blanchot 1955, 354). La imagen moderna no quiere ser ya lo que «viene después» de los objetos, sino, al contrario, lo que se pone antes y delante. No es otra la misión que emprende la fascinación. La imagen fascinante: donde se abisman los objetos, por donde se nos pierden, se nos alejan, se nos vuelven innombrables a fuerza de presencia de la propia imagen que los tiraniza, que los hace caer por detrás de ella misma. La imagen pone sus fuerzas en la disolución de los objetos. Su conquista -antiplatónica- no es otra que la de hacer desaparecer lo que hay: «La imagen exige la neutralidad y la borradura [effacement] del mundo, quiere que 
todo regrese al fondo indiferente donde nada se afirma, tiende a la intimidad de lo que subsiste aún en el vacío: ésta es su verdad. (Blanchot 1955, 345)7.

Por detrás de las imágenes presentándose -imponiéndosenos- se nos extrañan los objetos: la historia de la pintura moderna recorre los episodios de esta rebelión de las imágenes, artísticamente afanadas en no ser relegadas o postergados a una ontología subalterna. Las imágenes poniéndose por delante no sirven ya como medios de tránsito hacia los objetos. Recuperando en este punto el escrito de Heidegger sobre «La época de la imagen del mundo», podríamos suponer que la expansión de las imágenes implica a la vez la pérdida del propio mundo y sus objetos. Ya desde Chardin -al menos desde él...-, y con mayor conciencia a partir de Manet, Cézanne, Seurat, hasta llegar, si se quiere, hasta la metafísica chiriqueana, el dépaysement desplegado por Magritte, o incluso los hiperrealistas americanos del siglo XX, lo que se nos muestra con mayor precisión, con mayor rigor de evidencia, es justamente lo que menos poseemos. La representación meticulosa del mundo se produce a cambio de ir perdiendo la presencia (aquella de la que habla sin poder hablar el propio Lord Chandos). El mundo de las imagénes es el mundo disuelto en sus imágenes. Blanchot dice de la cosa que, «convertida en imagen, instantáneamente se transforma en lo inasible, lo inactual, lo impasible, no la misma cosa alejada, sino esta cosa como alejamiento, lo presente en su ausencia, lo aprehensible como inasible, apareciendo en tanto que desaparecida, el retorno de lo que no regresa, el corazón extraño de la lejanía como vida y corazón único de la cosa» (Blanchot, 1955, p. 347). Bien miradas, las imágenes viven de espantarnos; como quisiéramos espantar al que busca delatarnos.

7 Emmanuel Lévinas lo dice de este otro modo en su escrito de 1948 La realidad y su sombra: «El procedimiento más elemental del arte consiste en sustituir un objeto por su imagen. Imagen y no concepto. El concepto es el objeto captado, el objeto inteligible. Ya por la acción misma, mantenemos con el objeto real una relación viva, lo captamos, lo concebimos. La imagen neutraliza esta relación real, esta concepción original del acto. El famoso desinterés de la visión artística -en el que se detiene de hecho el análisis corriente de la estética- significa, ante todo, una ceguera ante los conceptos» (Lévinas 2001, 47). 


\section{REFERENCIAS BIBLIOGRÁFICAS}

ADORno, Th. W. 2004: Teoría estética. Madrid: Akal.

BAudelaire, Ch. 1968: Oeuvres complètes. Paris: Éd. du Seuil.

BARTHES, R. 1993: Fragmentos de un discurso amoroso. Madrid: Siglo XXI.

Benjamin, W. 1993: Poesía y capitalismo. Iluminaciones II. Madrid: Madrid.

BLANCHOT, M. 1955: L'espace littéraire. Paris: Gallimard.

Deleuze, G. 1969: Logique du sens. Paris: Éd. de Minuit.

ECO, U. 1985: Obra abierta. Barcelona: Ariel.

HEIDEGGER, M. 2005: Nietzsche. Barcelona: Destino.

KANT, I. 2003: Crítica del discernimiento. Madrid: Antonio Machado Libros.

LÉVINAS, E. 2001: La realidad y su sombra. Madrid: Trotta.

LYOTARD, J.-F. 1971: Discours, figure. Paris: Éd. Klincksieck.

PLATÓN 1998: Diálogos V. Madrid: Gredos.

Rosset, Cl. 2006: Fantasmagories, suivi de Le réel, l'imaginaire et l'illusoire. Paris: Éd. de Minuit.

SIMMel, G. 2001: El individuo y la libertad. Ensayos de crítica de la cultura. Barcelona: Península.

VALéRY, P. 1987: Escritos sobre Leonardo da Vinci. Visor: Madrid.

Luis Puelles es Profesor titular de Estética y Teoría de las Artes en la Universidad de Málaga. 
